\title{
Chemical Composition and Antioxidant Activity of Essential Oil of Sawdust from Moroccan Thuya (Tetraclinis articulata (Vahl) Masters
}

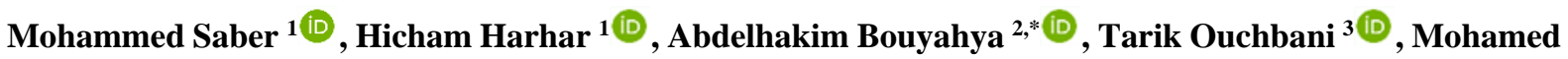 \\ Tabyaoui ${ }^{1}$ iD \\ 1 Laboratory of Nanotechnology, Materials \& Environment, Faculty of Sciences, Mohammed V University, Rabat, \\ Morocco, Avenue Omar Ibn El Khattab, BP 763 Agdal, 14000, Rabat, Morocco \\ 2 Laboratory of Human Pathologies Biology, Department of Biology, Faculty of Sciences, and Genomic Center of Human \\ Pathologies, Mohammed V University, Rabat, Morocco \\ 3 Department of Food and Nutritional Sciences, Hassan II Agronomic and Veterinary Institute, BP 6202 Rabat-Instituts, \\ Rabat; Morocco \\ * Correspondence: boyahyaa-90@ hotmail.fr;
}

Scopus Author ID 57190813643

Received: 6.06.2020; Revised: 2.07.2020; Accepted: 2.07.2020; Published: 5.07.2020

\begin{abstract}
The present study was dedicated to the study of the chemical composition and the antioxidant activity of the essential oils from the sawdust of Tetraclinis articulata in Morocco (from Khemisset region). The yield of the essential oil obtained by hydrodistillation from sawdust was $2.19 \%$. The determination of the chemical composition of Tetraclinis articulata essential oils (TAEO) was carried out by GC-SM analysis. The results that 22 volatile compounds were identified in the sawdust part of T. articulata, representing $87.25 \%$ of the total composition. The study of TAEO antioxidant activity was assessed by three different methods: the trapping of free radical DPPH, bleaching assay ABTS, and the reduction of iron (FRAP). The results of DPPH test showed that TAEO $\left(\mathrm{IC}_{50}=0.0144 \mathrm{mg} / \mathrm{mL}\right.$ ) has a very interesting antioxidant activity compared to the ascorbic acid used as reference $\left(\mathrm{IC}_{50}=0.0184\right.$ $\mathrm{mg} / \mathrm{mL}$ ). These results reveal promising prospects for the future exploitation of TAEO as a potential source of natural antioxidant substances that may be used for future investigations.
\end{abstract}

Keywords: Tetraclinis articulata; essential oils; GC-MS analysis; antioxidant effects.

(C) 2020 by the authors. This article is an open-access article distributed under the terms and conditions of the Creative Commons Attribution (CC BY) license (https://creativecommons.org/licenses/by/4.0/).

\section{Introduction}

Tetraclinis articulata (T. articulata) or Thuya of Berberia is also called Araar in Arabic. It is geographically present in three Maghreb countries (Morocco, Algeria, and Tunisia), in southeastern Spain (Almeria region), and on the island of Malta [1]. In Morocco, T. articulata forest has a very important role in the economic and social life of the local populations. Its wood, characterized by its strong resistance to rot, it is used principally in the craft sector for marquetry, cabinet making, and also for heating.

In traditional medicine, various parts are used mainly for the treatment of intestinal and respiratory infections, diabetes, and hypertension [2-7]. Pharmacological investigations reported on TAEO showed antibacterial, antifungal, antidiarrhoeal, anti-ulcerativecytotoxic, anti-Alzheimer, and anti-inflammatory activities [8-16]. 
Natural substances isolated medicinal plants have multiple interests in the industry, including cosmetics, food, and pharmaceuticals. Among these compounds, essential oils (EOs) or volatile compounds, clearly gain the interest of many investigators. Indeed, EOs have shown several biological effects, such as antimicrobial, anti-inflammatory, antioxidant, and antidiabetic properties [17-21].

On the other hand, oxidative stress is an escalating public health problem. Without adequate control, oxidative stress can lead to premature aging and significantly increase the risk of developing several diseases such as inflammation, diabetes, and cancer [22, 23]. Therefore, reducing oxidative stress with cytoprotective and antioxidating drugs seems to be a promising therapeutic solution [24]. Therefore, the research on a new source of antioxidants is necessary. In this context, a natural antioxidant such as EOs isolated from medicinal plants constitute a promising of these antioxidants. Indeed, current investigations have been oriented towards medicinal plants as a source of antioxidants and is particularly volatile compounds containing in their EOs.

Moroccan Thuya wood industry is dropping approximately tones of wood waste annually in the form sawdust. Due to global ecological and economic challenges, the aspect of this research is the transition of this waste to renewable resources. In this work, we are looking for new uses to be valorized from these wood rejects. Our interest in this present work is to study the chemical composition and the antioxidant activity by using DPPH, ABTS, and FRAP of TAEO collected from the Khemisset region of Morocco in order to develop a new type of disease control alternatives.

\section{Materials and Methods}

\subsection{Essential oil extraction.}

Sawdust of Thuya was collected in March 2017 from the industry of wood in Morocco (Khemisset area) and stored in the laboratory at room temperature $\left(25^{\circ} \mathrm{C}\right)$. The extraction of Thuya sawdust EOs was conducted by hydrodistillation using a Clevenger type apparatus [25]. This essential oil obtained was dried under anhydrous sodium sulfate and stored at $-5^{\circ} \mathrm{C}$ in the dark before analysis. The yield of the essential oil (\%) was calculated using the following formula (EO stands for essential oil):

$$
\text { Yield } \%=\frac{E O(g)}{\text { Sawdust Material }(g)} \times 100
$$

\subsection{Gas Chromatography (GC) and Gas Chromatography-Mass Spectrometry (GC/MS).}

The gas chromatography/mass spectrometry (GC/MS) device is made by Perkin Elmer Clarus TM GC-680 with Q-8 MS. It is equipped with an auto-sampler, which gives access to the automatic injection of samples into the injector and a capillary column type RxiR-5Sil MS traversed by Helium gas. The mass spectrometer is powered by a SMART electronic ionization source. This source can ionize and vaporize the different molecules as well as a quadrupole filter to separate the different ions in their $\mathrm{m} / \mathrm{z}$ ratio. The GC/MS system is computer-controlled with Turbomass (TM) software, which allows programming of analytical methods as well as qualitative and quantitative identification of detected species.

The analysis parameters are as follows: analysis time: 2 hours, vector gas flow rate: 1 $\mathrm{mL} / \mathrm{min}$, ionization energy: $70 \mathrm{eV}$, injector temperature: $260{ }^{\circ} \mathrm{C}$, oven temperature: $40{ }^{\circ} \mathrm{C}$ for 2 minutes, then rise from $10{ }^{\circ} \mathrm{C} / \min$ to $290{ }^{\circ} \mathrm{C}$, and the injected volume is $0.5 \mu \mathrm{L}$. 


\subsection{Antioxidant activity.}

In this study, three methods were used to evaluate the in vitro antioxidant activity of TAEO, namely the DPPH (1,1-diphenyl-2-picrylhydrazyl) method, ABTS bleaching assay, and the iron reduction method (FRAP).

\subsubsection{DPPH radical scavenging assay.}

The activity of the trapping of the radical DPPH was realized according to the protocol described by Lopes-Lutz et al. [26]. In test tubes, $2.5 \mathrm{~mL}$ of different concentrations are added to $1 \mathrm{~mL}$ of the methanol solution of DPPH $(0.3 \mathrm{mM})$. After 30 minutes of incubation in the dark and at room temperature, the absorbances are measured using a spectrophotometer at 517 nm against a blank that contains pure methanol. The negative control was prepared by mixing $1 \mathrm{~mL}$ of the DPPH methanol solution $(0.3 \mathrm{mM})$ and $2.5 \mathrm{~mL}$ of methanol.

\subsubsection{ABTS radical scavenging assay.}

A solution of ABTS radical is prepared by mixing $2 \mathrm{mM}$ ABTS with $70 \mathrm{mM}$ potassium persulfate solution. The mixture is allowed to stir for 24 hours in the dark and at room temperature before use. This solution is then diluted with methanol to have an absorbance of $0.700 \pm 0.02$ at $734 \mathrm{~nm}$. Then, $2 \mathrm{~mL}$ of this solution, $200 \mu \mathrm{L}$ of essential oil or positive control is added, after $30 \mathrm{~min}$. The absorbance obtained at $734 \mathrm{~nm}$ is noted [27].

\subsubsection{FRAP iron reduction test.}

The reducing power of iron $\left(\mathrm{Fe}^{3+}\right)$ of TAEO is determined by the method described by Oyaizu [28], with some modifications. Briefly, $1 \mathrm{~mL}$ of different concentrations was mixed with $2.5 \mathrm{~mL}$ of a phosphate buffer solution $0.2 \mathrm{M}(\mathrm{pH} 6.6)$ and $2.5 \mathrm{~mL}$ of potassium ferricyanide $\mathrm{K}_{3} \mathrm{Fe}(\mathrm{CN})_{6}(1 \%)$ solution. The mixture is incubated in a water bath at $50^{\circ} \mathrm{C}$ for 20 minutes. Then $2.5 \mathrm{~mL}$ of trichloroacetic acid (10\%) is added to stop the reaction, and the tubes are centrifuged at $3000 \mathrm{rpm}$ for $10 \mathrm{~min}$. An aliquot $(2.5 \mathrm{~mL})$ of supernatant is mixed with $2.5 \mathrm{~mL}$ of water and $0.5 \mathrm{~mL}$ of aqueous $\mathrm{FeCl}_{3}$ solution $(0.1 \%)$. The absorbance of the reaction medium was read at $700 \mathrm{~nm}$ against a blank using a UV-VIS spectrophotometer. An augmentation in absorbance corresponds to an augmentation in the reducing power of the samples tested [29]. For all antioxidants tests, the positive control is represented by a solution of a standard antioxidant (ascorbic acid) prepared under the same conditions as the sample. Each test was carried out in triplicate.

\section{Results and Discussion}

\subsection{Essential oils yield and chemical composition.}

The yields of essential oil of sawdust, calculated after 6 hours of extraction is $2.19 \%$. Different yields have been revealed in the literature, particularly in Morocco. The yield of $T$. articulata sawdust collected in the Khemisset region in 2007 was of the order of $1.63 \%$ [30]. This yield is lower than ours $(2.19 \%)$.

The GC-MS analysis of TAEO revealed the presence of 22 volatile compounds. These compounds are belonging to different classes, including oxygenated monoterpenes, $(49.2 \%)$, Sesquiterpene hydrocarbons (22.38\%), oxygenated sesquiterpenes (10.30\%), and monoterpene 
hydrocarbons (2.12\%). The major compounds of TAEO are carvacrol (20.59\%), acetoveratrone (17.47\%), cedrol (10.30\%), and $\alpha$-Cedrene $(8.99 \%)$ (Table 1$)$.

Our results differ considerably from those reported in the literature. Indeed, Barrero et al., (2005) who identified cedrol, 1,7-di-epi-cedrol, and 1,7-di-epi-isocedrol as the most abundant compounds in sawdust oil [31]. In another study, Zrira et al., have reported a chemical composition of sawdust oil dominated by carvacrol, $\alpha$-cedrene, cedrol, and terpinen-4-ol [32]. Other authors have identified other major compounds as carvacrol, cedrol, paramethoxythymol, and thymohydroquinone [33]. In the Khemisset sawdust essential oil produced in 2007, Bourkhiss et al., reported the presence of $\alpha$-acorenol (20.9\%), cedrol $(17.9 \%)$, totarol $(8.8 \%), \alpha$-cedrene $(8.7 \%) . \%)$ and $\beta$-acorenol $(7.4 \%)$ as major constituents [30]. Satrani cited 2,5dimethoxy-acetophenone (22.5\%), $\beta$-acorenol (20.4\%) and cedrol $(12.2 \%)$ as majority compounds in sawdust essential oil collected in Morocco [34]. The components of our oil were divided into five classes: monoterpene hydrocarbons, oxygenated monoterpenes, sesquiterpene hydrocarbons, oxygenated sesquiterpenes, and others. The results show that oxygenated monoterpenes (49.2\%) and Sesquiterpene hydrocarbons (22.38), constituted the principal compound classes represented in the essential oils of sawdust, than Sesquiterpene hydrocarbons $(10.30 \%)$ and oxygenated sesquiterpenes (3.91\%), (Table 1). The comparative studies carried out in the literature of the T. articulata reveal the heterogeneity of the majority compounds $[35,36]$. However, the chemical composition of the essential oil in general and the majority compounds, in particular, vary quantitatively and qualitatively under the effect of several factors such as the ecological conditions, the geographical origin, the analyzed part of the species, the mode of extraction, and the period of harvest $[34,37,38]$.

Table 1. Chemical composition of the essential oil from TAEO.

\begin{tabular}{lcc} 
Compounds & Retention indices & \% Area \\
\hline Terpinene-4-ol & 7.745 & 1.56 \\
\hline 2-carene & 7.941 & 0.44 \\
\hline Thymyl methyl ether & 8.725 & 3.86 \\
\hline Thymoquinone & 8.836 & 0.89 \\
\hline Carvenone & 8.969 & 1.21 \\
\hline Carvacrol & 9.588 & 20.59 \\
\hline$\alpha$-Cedrene & 11.309 & 8.99 \\
\hline$\alpha$-copaene & 11.436 & 1.87 \\
\hline Acoradiene & 11.992 & 2.65 \\
\hline Acetoveratrone & 12.162 & 17.47 \\
\hline 2,5-Dimethoxyacetophenone & 12.267 & 1.86 \\
\hline p-Cresol & 12.405 & 0.69 \\
\hline$\alpha$-Curcumene & 12.564 & 0.44 \\
\hline$\gamma$-Pyronene & 12.622 & 1.02 \\
\hline Cedrol & 13.877 & 10.30 \\
\hline Piperonylamine & 14.041 & 0.8 \\
\hline Cedr-9-ene & 14.184 & 4.88 \\
\hline$\beta$-Curcumene & 14.232 & 3.55 \\
\hline allo-Ocimene & 15.990 & 0.66 \\
\hline Isopropylphenol & 16.181 & 1.07 \\
\hline Totarol & 21.836 & 1.28 \\
\hline Carbofuran & 22.667 & 1.83 \\
\hline Monoterpene hydrocarbons & & 2.12 \\
\hline Oxygenated monoterpenes & & 49.2 \\
\hline Sesquiterpene hydrocarbons & & 22.38 \\
\hline Oxygenated sesquiterpenes & & 10.30 \\
\hline Others & & 3.91 \\
\hline Total & & 87.25 \\
\hline
\end{tabular}




\subsection{Antioxidant activity of essentials oils.}

The results of the antioxidant effect of TAEO are expressed as the percentage of inhibition, as shown in figures 1,2 , and 3. It was noted that the percentages of inhibition antioxidant increase with increasing concentration of TAEO and ascorbic acid used as a reference antioxidant.

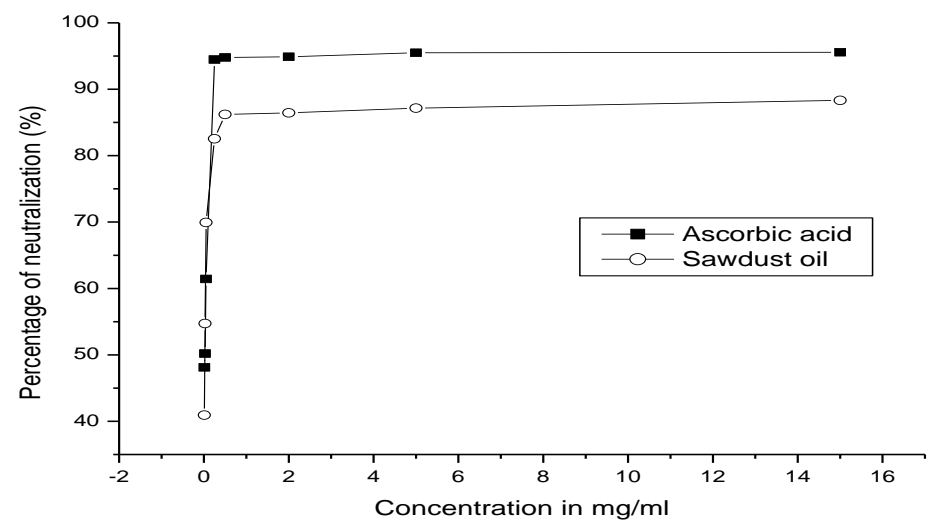

Figure 1. Evolution of percentage neutralization (\%) obtained by the DPPH Test for TAEO and ascorbic acid.

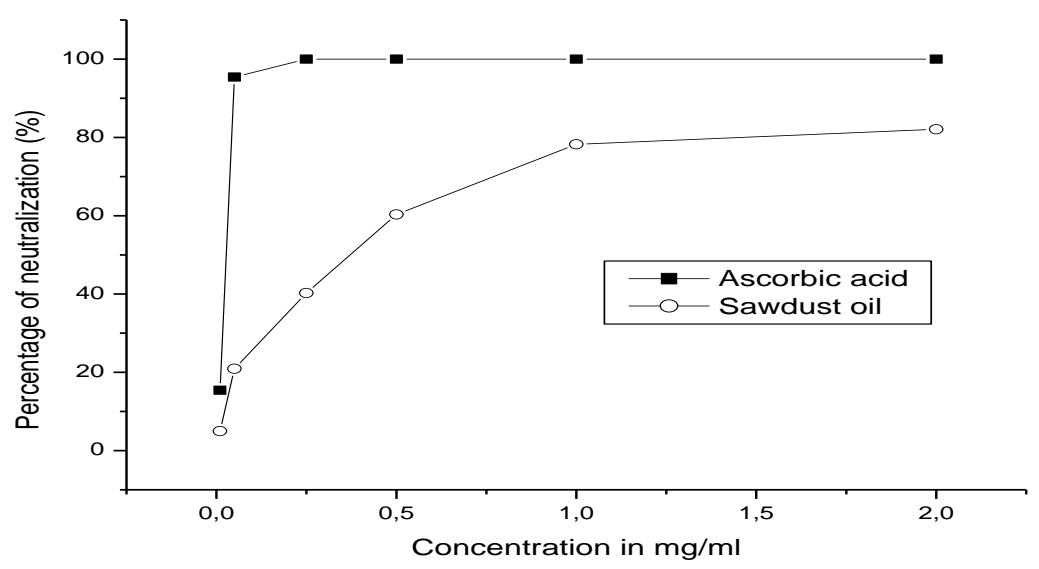

Figure 2. Evolution of percentage neutralization (\%) obtained by the ABTS Test for TAEO and ascorbic acid.

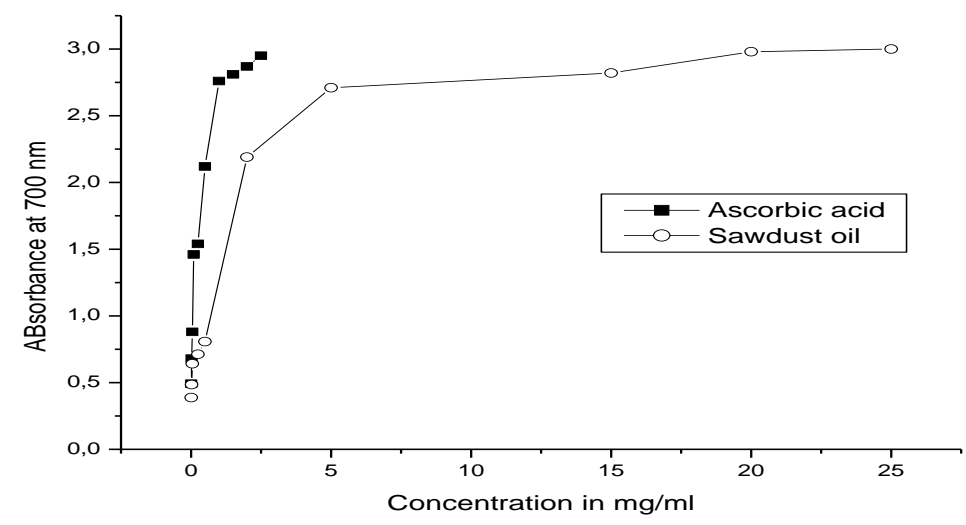

Figure 3. Graph showing the reducing power FRAP of TAEO compared with that of ascorbic acid.

The antioxidant activity of TAEO for DPPH and ABTS is expressed as $\mathrm{IC}_{50}$, which defines the concentration of the tested sample needed to reduce $50 \%$ of oxidants. In addition, 
the more the value of the $\mathrm{IC}_{50}$ is small, the more the plant has a strong anti-radical effect. For the FRAP test, the results are expressed as the $\mathrm{EC}_{50}$ values, which are defined as the effective concentrations at which the absorbance is equal to 0.5. The exploitation of the results for the FRAP test was carried out following the evolution of the absorbance according to different concentrations of the oil studied. The results of Figure 3 showed that reducing power (FRAP) of TAEO increases with increasing concentration.

The $\mathrm{IC}_{50}$ and $\mathrm{EC}_{50}$ values are calculated graphically by the linear regression of the graphs plotted previously (Figures 1, 2, and 3). The results are summarized in Table 2.

Table 2. Antioxidant activity of Sawdust essential oil from Thuya and ascorbic acid.

\begin{tabular}{l|c|c|c} 
& DPPH $\left(\mathbf{I C}_{\mathbf{5 0}} \mathbf{~ m g} / \mathbf{m L}\right)$ & ABTS $\left(\mathbf{I C}_{\mathbf{5 0}} \mathbf{~ m g} / \mathbf{m L}\right)$ & FRAP $\left(\mathbf{E C}_{\mathbf{5 0}} \mathbf{~ m g} / \mathbf{m L}\right)$ \\
\hline Sawdust oil & 0.0144 & 0.38205 & 0.02915 \\
\hline Ascorbic acid & 0.0184 & 0.03544 & 0.01062
\end{tabular}

The calculated $\mathrm{IC}_{50}$ and $\mathrm{EC}_{50}$ values for our oil confirmed the reactivity of this samples opposite to the oxidants; this high activity of neutralization of the DPPH radicals in comparison with the reference antioxidant (AA), the EOs obtained from sawdust is more active (IC ${ }_{50}=0.01444 \mu \mathrm{g} / \mathrm{mL}$ ) than the reference antioxidant $\left(\mathrm{IC}_{50}=0.0184 \mu \mathrm{g} / \mathrm{mL}\right.$ ) this can be attributed to the higher percentage of carvacrol which represents $18.78 \%$ of the total oil, this compound is recognized in the literature by its high antioxidant power $[39,40]$. In the FRAP method, the reduction activities revealed for the sawdust oil is active $\left(\mathrm{EC}_{50}=0.029 \mathrm{mg} / \mathrm{mL}\right)$ but lower than the reference antioxidant (ascorbic acid EC $50=0.01 \mathrm{mg} / \mathrm{mL}$ ).

In comparison with the literature, the results obtained are superior to those revealed by El Jemli and collaborators who worked on TAEO leaves of the Marrakech region $\left(\mathrm{IC}_{50}=12.05 \pm 0.24 \mathrm{mg} / \mathrm{mL}\right)$ [4], and those obtained in the three regions of Algeria namely: Zeddine ( $\mathrm{IC}_{50}=113.47 \pm 4.19 \mathrm{mg} / \mathrm{mL}$ ), Mansoura $\left(\mathrm{IC}_{50}=125.75 \pm 3.33 \mathrm{mg} / \mathrm{mL}\right.$ and Tazoult $\left(\mathrm{IC}_{50}=252.49 \pm 6.14 \mathrm{mg} / \mathrm{mL}\right)[10]$.

These results are considered important, especially in the food industry, because TOEO did not show in vivo toxicity on human health and, therefore, can be added to food for conservation [41].

\section{Conclusions}

The aromatic plants are currently a reliable source of active ingredients recognized by their therapeutic properties, including antioxidant activities. This work was focused on the study of the chemical composition and the antioxidant activity of TAEO. The chemical composition analysis of the essential oils by GPC-MS identified 22 compounds with carvacrol as the major compounds. The results of the antioxidant activity showed that this sawdust oil has a strong antioxidant activity. However, sawdust oil is just waste from wood processing and the manufacture of panels and furniture. This study can find an important application in the pharmaceutical industry and the food industry. However, further investigations should be carried out to determine the antioxidant effects of TAEO bioactive compounds and their applications in the food industry.

\section{Funding}

This research received no external funding. 


\section{Acknowledgments}

This research has no acknowledgment.

\section{Conflicts of Interest}

The authors declare no conflict of interest.

\section{References}

1. Achhal, A.; Barbero, M.; Ech-Chamikh, S.J.E.M. Productivité du thuya (Tetraclinis articulata (Vahl) Masters) dans le bassin versant du N'Fis. Ecologia Mediterranea 1985, 11, 201-212, https://doi.org/10.3406/ecmed.1985.1106.

2. Bellakhdar, J.; Claisse, R.; Fleurentin, J.; Younos, C.J.J.O.E. Repertory of standard herbal drugs in the Moroccan pharmacopoea. Journal of Ethnopharmacology 1991, 35, 123-143, https://doi.org/10.1016/03788741(91)90064-k.

3. Ziyyat, A.; Legssyer, A.; Mekhfi, H.; Dassouli, A.; Serhrouchni, M.; Benjelloun, W.J.J.O.E. Phytotherapy of hypertension and diabetes in oriental Morocco. Journal of Ethnopharmacology 1997, 58, 45-54, https://doi.org/10.1016/s0378-8741(97)00077-9.

4. El Jemli, M.; Kamal, R.; Marmouzi, I.; Doukkali, Z.; Bouidida, E. H.; Touati, D.; Nejjari, R.; El Guessabi, L.; Cherrah, Y.; Alaoui, K.J.O.T. Chemical composition, acute toxicity, antioxidant and anti-inflammatory activities of Moroccan Tetraclinis articulata L. Journal of Traditional and Complementary Medicine 2017, 7, 281-287, https://doi.org/10.1016/j.jtcme.2016.06.006.

5. Idm'hand, E.; Msanda, F.; Cherifi, K.J.C.P. Ethnopharmacological review of medicinal plants used to manage diabetes in Morocco. Clinical Phytoscience 2020, 6, 1-32, https://doi.org/10.1186/s40816-02000166-z.

6. Rabib, H.; Zougagh, S.; Hsain, M.; Badri, W.; Koussa, T.J.M.J.O.C. GC/MS Analysis and Antibacterial Activity of the Essential Oil of Moroccan Tetraclinis articulata (Vahl) Masters. Mediterranean Journal of Chemistry 2019, 8, 302-307, https://doi.org/10.13171/mjc84190706041316hr.

7. Zahir, I.; Elazaoui, S.; Chakouri, M.; Naouer, B.J.E.R. Applications. Étude ethnobotanique de Tetraclinis articulata dans la région de Béni Mellal-Khénifra. Ethnobotany Research and Applications 2020, 19, 1-22, https://doi.org/10.32859/era.19.36.1-22.

8. Rached, W.; Zeghada, F.Z.; Bennaceur, M.; Barros, L.; Calhelha, R.C.; Heleno, S.; Alves, M.J.; Carvalho, A.M.; Marouf, A.; Ferreira, I.C.J.I.C. Products. Phytochemical analysis and assessment of antioxidant, antimicrobial, anti-inflammatory and cytotoxic properties of Tetraclinis articulata (Vahl) Masters leaves. Industrial Crops \& Products 2018, 112, 460-466, https://doi.org/10.1016/j.indcrop.2017.12.037.

9. Abi-Ayad, F.Z.; Abi-Ayad, M.; Lazouni, H.A.; Rebiahi, S.A. Evaluation of Tetraclinis articulata essential oil from Algeria flora as a potential source of antifungal activity and study of its chemical composition. Journal of the Indian Academy of Wood Science 2013, 10, 9-15, https://doi.org/10.1007/s13196-013-00867.

10. Djouahri, A.; Saka, B.; Boudarene, L.; Lamari, L.; Sabaou, N.; Baaliouamer, A.J.C. Biodiversity. Essential Oil Variability of Tetraclinis articulata (Vahl) Mast. Parts During Its Phenological Cycle and Incidence on the Antioxidant and Antimicrobial Activities. Chemistry \& Biodiversity 2017, 14, https://doi.org/10.1002/cbdv.201600216.

11. Sadiki, F.Z.; El Idrissi, M.; Sbiti, M.; Lemrhari, A.; Trifan, A.; Cioanca, O.; Postu, P.A.; Hritcu, L.J.C.; Agriculture, B.T. Chemical composition and antibacterial activity of essential oil of Tetraclinis articulata (Vahl) Masters branches of eastern Morocco. Chemical and Biological Technologies in Agriculture 2018, 5, https://doi.org/10.1186/s40538-018-0137-9.

12. Boubaker, H.; Karim, H.; Msanda, F.; Boudyach, E.H.; Aoumar, A.A.B. Study of Essential Oil Composition and Antifungal Activity of Lavandula mairei, L. dentata and Tetraclinis articulata. Journal of Applied Sciences 2019, 19, 544-550, http://dx.doi.org/10.3923/jas.2019.544.550.

13. Zerkani, H.; Tagnaout, I.; Dirioiche, A.; Adadi, I.; El Karkouri, J.; Padzys, G. S.; Zair, T. J. M. J. o. C. Chemical characterization and antibacterial activity of the essential oils of Tetraclinis articulata (Vahl) from Morocco. Mediterranean Journal of Chemistry 2018, 8, 390-396, https://doi.org/10.13171/mjc851907076hz.

14. Ababsa, Z.E.A.; Derouiche, M.T.; Medjroubi, K.; Akkal, S.J. In-vivo Antidiarrhoeal and anti-ulcerative activities of the Tetraclinis articulata species of the Cupressaceae family. Acta Scientifica Naturalis 2019, 6, 50-53, https://doi.org/10.2478/asn-2019-0007.

15. Sadiki, F.Z.; El Idrissi, M.; Cioanca, O.; Trifan, A.; Hancianu, M.; Hritcu, L.; Postu, P.A. Tetraclinis articulata essential oil mitigates cognitive deficits and brain oxidative stress in an Alzheimer's disease amyloidosis model. Phytomedicine 2019, 56, 57-63, https://doi.org/10.1016/j.phymed.2018.10.032. 
16. Rguez, S.; Slimene, I.B.; Abid, G.; Hammemi, M.; Kefi, A.; Elkahoui, S.; Ksouri, R.; Sellami, I.H.; Djébali, N.J. Tetraclinis articulata essential oil reduces Botrytis cinerea infections on tomato. Scientia Horticulturae 2020, 266, https://doi.org/10.1016/j.scienta.2020.109291.

17. Shah, M.; Alharby, H.F.; Hakeem, K.R.; Lantana camara: A Comprehensive Review on Phytochemistry, Ethnopharmacology and Essential Oil Composition. Lett. Appl. NanoScience 2020, 9, 11991207.

18. El-Saber Batiha, G.; Magdy Beshbishy, A.; Wasef, L.G.; Elewa, Y.H.; A Al-Sagan, A.; El-Hack, A.; Mohamed, E.; Taha, A.E.; Abd-Elhakim, Y.M.; Prasad Devkota, H.J.N. Chemical constituents and pharmacological activities of garlic (Allium sativum L.): A review. Nutrients 2020, 12, https://dx.doi.org/10.3390\%2Fnu12030872.

19. Bouyahya, A.; Belmehdi, O.; Benjouad, A.; El Hassani, R. A.; Amzazi, S.; Dakka, N.; Bakri, Y.J.I.C. Products. Pharmacological properties and mechanism insights of Moroccan anticancer medicinal plants: What are the next steps? Industrial Crops and Products 2020, 147, https://doi.org/10.1016/j.indcrop.2020.112198.

20. Chitkara, M.; Sindhu, R.K.; Singh, I.; Kumar, D.; Sandhu, I.S.; Arora, S. Formulation and Evaluation of Essential Oils based Liquid Herbal Hand Wash. Research Journal of Pharmacy and Technology 2020, 13, 1917-1920, https://doi.org/10.5958/0974-360X.2020.00345.5.

21. Klimek-Szczykutowicz, M.; Szopa, A.; Ekiert, H.J.P. Citrus limon (Lemon) Phenomenon-A Review of the Chemistry, Pharmacological Properties, Applications in the Modern Pharmaceutical, Food, and Cosmetics Industries, and Biotechnological Studies. Plants 2020, 9, https://doi.org/10.3390/plants9010119.

22. Poprac, P.; Jomova, K.; Simunkova, M.; Kollar, V.; Rhodes, C. J.; Valko, M. Targeting free radicals in oxidative stress-related human diseases. Trends in Pharmacological Sciences 2017, 38, 592-607, https://doi.org/10.1016/j.tips.2017.04.005.

23. Fulop, T.; Pawelec, G.; Dupuis, G.; Kotb, R.; Friguet, B.; Witkowski, J.M.; Larbi, A. Immunosenescence, oxidative stress, and cancers. In: Cancer Immunology. Springer, 2020; pp 513-531, https://doi.org/10.1007/978-3-030-30845-2_23.

24. Das, A.K.; Nanda, P.K.; Madane, P.; Biswas, S.; Das, A.; Zhang, W.; Lorenzo, J.M. A comprehensive review on antioxidant dietary fibre enriched meat-based functional foods. Trends in Food Science \& Technology 2020, 99, 323-336, https://doi.org/10.1016/j.tifs.2020.03.010.

25. Clevenger, J.F. Apparatus for the determination of volatile oil. Journal of the American Pharmacists Association 1928, 17, 345-349, https://doi.org/10.1002/jps.3080170407.

26. Lopes-Lutz, D.; Alviano, D.S.; Alviano, C.S.; Kolodziejczyk, P.P. Screening of chemical composition, antimicrobial and antioxidant activities of Artemisia essential oils. Phytochemistry 2008, 69, 1732-1738, https://doi.org/10.1016/j.phytochem.2008.02.014

27. Müller, L.; Fröhlich, K.; Böhm, V. Comparative antioxidant activities of carotenoids measured by ferric reducing antioxidant power (FRAP), ABTS bleaching assay ( $\alpha$ TEAC), DPPH assay and peroxyl radical scavenging assay. Food Chemistry 2011, 129, 139-148, https://doi.org/10.1016/j.foodchem.2011.04.045.

28. Oyaizu, M. Studies on products of browning reaction. The Japanese Journal of Nutrition and Dietetics 1986 , 44, 307-315, https://doi.org/10.5264/eiyogakuzashi.44.307.

29. Singleton, V. L.; Rossi, J.A. Colorimetry of total phenolics with phosphomolybdic-phosphotungstic acid reagents. American journal of Enology and Viticulture 1965, 16, 144-158.

30. M'barek, B.; Mohamed, H.; Julien, P.; Jean, C.; Abdelaziz, C. Composition chimique des huiles essentielles de la sciure de bois et de feuilles de Tetraclinis articulata (Vahl) Masters du Maroc. Bulletin de la Société Royale des Sciences de Liège 2009.

31. Barrero, A.; Herrador, M.; Arteaga, P.; Quilez, J.; Akssira, M.; Mellouki, F.; Akkad, S. Chemical composition of the essential oils of leaves and wood of Tetraclinis articulata (Vahl) Masters. Journal of Essential Oil Research 2005, 17, 166-168, https://doi.org/10.1080/10412905.2005.9698865.

32. Zrira, S.; Benjilali, B.; Elamrani, A. Chemical composition of the sawdust oil of Moroccan Tetraclinis articulata Vahl. Journal of Essential Oil Research 2005, 17, 96-97, https://doi.org/10.1080/10412905.2005.9698842.

33. Ait Igri, M.; Holeman, M.; Idrissi, A.; Berrada, M. Contribution al'étude chimique des huiles essentielles des rameaux et du bois de Tetraclinis articulata (VAHL) Masters. Plant. Med.Phytother 1990, 24, 36-43.

34. Satrani, B. Valorisation de plantes aromatiques et médicinales par l'analyse chimique et l'étude de la bioactivité de leurs huiles essentielles. 2006.

35. Bourkhiss, M.; Chaouch, A.; Ouhssine, M.; Bourkhiss, B.J.P. Étude comparative de la composition chimique des huiles essentielles de Tetraclinis articulata (Vahl) Masters du Maroc. Phytothérapie 2018, 18, 2-5, https://doi.org/10.3166/phyto-2018-0082.

36. Jlizi, S.; Zardi-Bergaoui, A.; Znati, M.; Flamini, G.; Ascrizzi, R.; Jannet, H.B. Products. Chemical composition and biological evaluation of the resin from Tetraclinis articulata (Vahl.) Masters: A promising source of bioactive secondary metabolites. Industrial Crops and Products 2018, 124, 74-83, https://doi.org/10.1016/j.indcrop.2018.07.055.

37. El Abed, D.; Kambouche, N. Oran, 91p. Les huiles essentielles. 2003. 
38. Bourkhiss, B.; Ouhssine, M.; Hnach, M.; Bourkhiss, M.; Satrani, B.; Farah, A. Composition chimique et bioactivité de l'huile essentielle des rameaux de Tetraclinis articulata. Bull. Soc. Pharm. Bordeaux 2007, 146, 75-84.

39. Ruberto, G.; Baratta, M.T. Antioxidant activity of selected essential oil components in two lipid model systems. Food Chemistry 2000, 69, 167-174, https://doi.org/10.1016/S0308-8146(99)00247-2.

40. Kulisic, T.; Radonic, A.; Katalinic, V.; Milos, M. Use of different methods for testing antioxidative activity of oregano essential oil. Food Chemistry 2004, 85, 633-640, https://doi.org/10.1016/j.foodchem.2003.07.024.

41. Benyamina, A.; Toumi, F.; Soltani, Y. J. P. Toxicité aiguë et activité anti-inflammatoire et analgésique des feuilles de Tetraclinis articulata (Vahl) Mast. in vivo. Phytothérapie 2018, https://doi.org/10.3166/phyto2018-0000. 